УДК 82.091: 821.161.2+821.111

\title{
THE REPRESSIVE POLICY OF THE POLISH AUTHORITIES AGAINST THE GREEK CATHOLIC CLERGY 1919-1921
}

\author{
Олег СГРЕШІЙ \\ Державний вищий навчальний заклад \\ "Прикарпатський національний університет імені Василя Стефаника", \\ кафедра історії Украӥни і методики викладання історії, \\ вул. Шевченка, 57, 76018, Івано-Франківськ, Україна \\ e-mail:ludyna@ukr.net \\ DOI: 10.15330/gal.32.67-73 \\ ORCID: 0000-0002-0639-910X
}

У науковій статті автор розкриває ставлення польських урядових структур до українського греко-католицького духівництва в Галичині 1919-1921 рр. Автор визначає характер репресій щодо священиків у циьому регіоні.

Зазначається, щзо 22 червня 1919 р. частина священиків, зокрема, о. Анатоль Долинський, о. Іван Галібей, о. Микола Никлич опинилися у Львівській в'язниці “Бригідки”. Окремих отців було перевезено до табору полонених “На Засянню”, щуо у Перемишлі. Деякі священики опинилися в таборі для полонених у Стшалково, щчо поблизу Познаня. Серед отиів, щзо перебували в Стшалково: о. Микола Конрад з Тернополя, о. Василь Дубицький і Михайло Осадиза з Бережан, о. Микола Сіменович зі Стриганців, о. Володимир Стернюк з Пустомит, о. Іван Галібей (польовий духівник УГА), о. Антін Твердохліб з Краківия, о. Андрій Дольницький з Сіверян, о. Григорій Музичка з Журавно, о. Антін Сірецький з Лячького Шляхецького.

Автор зазначає, щзо вище духовенство також зазнало переслідувань. У листопаді 1918 р. було проведено обшук у помешканні перемишльського єпископа Йосафата Кочиловського. Значний резонанс 8 східногалицькому суспільстві отримав домашній арешт (конфінування) митрополита Греко-католицької Церкви Андрея Шептицького польськими властями 23 серпня 1923 р. у монастирі Шариток у Познані. 3 різних куточків Галичини духовенство ГКЦ направило лист-протест на ім'я президента Речі Посполитої Станіслава Войцеховського.

У статті акиентується. щзо священики Бережанського (о. Богдан Кордуба, канонік львівської капітули, о. Омелян Кордуба, о. Іван Романчукевич, о. Пилип Сверчук з Вільхівців, о. Стефан Комар парох Ценеви, о. Іван Пінковський - парох Вибудова) та Бобрецького деканату (о. Віктор Несторович, о. Володимир Дорош, о. Михайло Кравчук) Львівської архієпархї взяли участь у численних віче за участі українських громадсько-політичних та просвітницьких діячів у вересні 1923 р.

У науковій статті також зазначається, щцо помітну активність проявило греко-католицьке духовенство під час проведення перепису населення у вересні 1921 p. Загальний перепис населення 1921 р. перетворився на своєрідний антиокупаційний плебісичит.

Ключові слова: греко-католицьке духовенство, репресивна політика, польські урядові структури, конфінування, арешти.

Ukrainian-Polish relations at the present stage, in our opinion, are ambiguous. On the one hand, it is about neighbornood, on the other-there are many questionss of a historical nature. They are still the subject of heated discussions between Ukrainian and Polish historians. Many controversial questions also relate to the situation of the Greek Catholic Church in the Polish state of the interwar period. The Greek Catholic Church was deservedly regarded as well as a national church because of the great authority of its leader of Metropolitan Andrei Sheptytskyi.

The problem of the attitude of the Polish authorities to the Greek-Catholic clergy has repeatedly became the subject of a study by Ukrainian researchers. We distinguish the work of the scientists: Vasyl Marchuk ${ }^{1}$, Vitalii Perevezii ${ }^{2}$, Mykhailo Haikovskyi ${ }^{3}$, Ihor Pylypiv ${ }^{4}$, Volodymyr

\footnotetext{
${ }^{1}$ Марчук В. Українська Греко-Католицька Церква. Історичний нарис. Івано-Франківськ : Плай, 2001. 164 с. ; Марчук В., Пилипів I. Українська греко-католицька церква й українська держава. Украйнознавчі cmydiï. 2000. № 2. C. 205-223.
} 
68

Komar $^{5}$, Orest Krasivskyi ${ }^{6}$, Ruslan Delyatynskyi ${ }^{7}$. However, less attention was paid to the question of the repressive policy of the Polish authorities in Galicia during 1919-1921. The purpose of the article is to reveal the attitude of Polish government structures towards the Ukrainian Greek Catholic clergy in Galicia from 1919-1921, and to determine the nature of repressions against priests in this region.

The revival of the independent Polish Republic on November 11, 1918 was marked by active actions of foreign policy in the eastern direction ${ }^{8}$. During May-July 1919 the whole territory of Eastern Galicia was occupied and gradually integrated by Polish troops. Immediately introduced a state of emergency, abolished only in 1922, and the Polish administration launched repressions. In order to increase the number of Polish population in January 1920, a new political and administrative division of Eastern Galicia was introduced into three districts - Lviv (28 counties), Stanislaviv (16 counties) and Ternopil (17 counties). Thus, the Greek Catholic Church was in the new socio-political realities. It should be noted that the repressive policy of the Polish authorities against the Greek Catholic clergy during 1919-1921 was not "one-dimensional", but was manifested in various means and methods. The most radicals of clerics were arreste.

On June 22, 1919 many Greek Catholic priests from different parts of Galicia: Anatol Dolyńskii, Ivan Halibei, Mykola Nyklych and others were taken to Lviv prison "Bridgits" without any guilt. Priests were often along with political criminals there. In total, 113 priests were in Prison. On July 10, 1919, the priests were taken to the prison camp "At Zasianny", which was in Przemysl, under absolutely unsuitable conditions (the prisoners were placed in a freight train). In the camp, priests were not usual allowed to take with them their money, linens, sugar'.

Some of the priests founded themselves in a camp for prisoners at Sthalkovo near Poznan. In the priests camp they were deprived of personal belongings (picked up watches, clothes, shoes, etc.). In the camp there was no warm water, spotted typhus spread. Priests lived in underground huts, slept on the naked floor without straw. After two weeks, the attitude of the priests improved somewhat. The Human Rights Commission, accompanied by a foreign mission, arrived from Warsaw, heard a complaint and the prisoners were soon deployed in the overhangs.

In Sthalkovo, the priests divided the camp into five "parochial parishes" with the "pastorscollaborators". In the "parish chapels", which were often served in the dining rooms, worship was given, sermons were proclaimed, holy secrets of the Eucharist were given. The priests stayed in the

\footnotetext{
${ }^{2}$ Перевезій В. Греко-католицька церква в умовах українсько-польської конфронтації 20-30-х pp. XX ст. Київ, 1998. 46 с.

${ }^{3}$ Гайковський М. УГКЦ в часи митрополитування Андрея Шептицького. Київька Церква. 2001. № 2-3. С. $32-48$.

${ }^{4}$ Пилипів І. В. Греко-католицька церква в суспільно-політичному житті Східної Галичини (19181939 рр.) : моногр. Тернопіль : Економічна думка ТНЕУ, 2011. 440 с.

${ }_{5}$ Комар В. Л. Концепція прометеїзму в політиці Польщі (1921-1939 рр.). Івано-Франківськ : Місто НВ, $2011.360 \mathrm{c}$.

${ }^{6}$ Красівський О., Пилипів I. Митрополит Андрей Шептицький і польська держава (1918-1923рр.). Українсько-польські відносини в Галичині у ХХ cm. : Матеріали міжнародної науково-практичної конференції (21-22 листопада 1996 р.). Івано-Франківськ : Плай, 1997. С. 152-155.

7 Делятинський Р. І. Становище та діяльність духовенства Станіславської єпархії УГКЦ в 1919-1920рр. Вісник Прикарпатського університету. Історія. Вип. VII. Івано-Франківськ, 2003. С. 69-77 ; Делятинський Р. Регулювання правового статусу греко-католицької Церкви в контексті подій радянсько-польської війни у 1920-1921 pp. (на прикладі Станіславівської єпархії). Україна соборна : збірник наукових статей / ред. кол.: О. П. Реєнт (відп. ред.) та ін. Київ : Ін-т історії України НАН України, 2005. Вип. 2. Ч. 2 : Соціокультурні, етноконфесійні та демографічні проблеми формування української нації. С. 309-320 ; Делятинський Р. І. Діяльність духовенства Станиславівської єпархії УГКЦ в умовах утвердження польського окупаційного режиму (1920-1923 pp.). URL: http://thule.primordial.org.ua/mesogaia/ delyat03.htm.

${ }^{8}$ Комар В. Л Концепція прометеїзму в політиці Польщі (1921-1939 рр.). Івано-Франківськ : Місто НВ, 2011. С. 74-84.

${ }^{9}$ Центральний державний історичний архів України у Львові (далі - ЦДІАУ у Львові). Ф. 408 (Грекокатолицький митрополичий ординаріат м. Львів). Оп. 1. Спр. 47 (Обіжники, розпорядження, протести, скарги, списки арештованих та ін. документи про переслідування греко-католицької церкви польською владою 1919-1938 рр.). Арк. 3, 8.
} 
camp until January 2, 1920. Among the priests who were in Stshalkovo: Mykola Konrad from Ternopil, Vasyl Dubitskyi and Mykhailo Osadtsa from Berezhany, Mykola Semenovych from Strihantsi, Volodymyr Sterniuk from Pustomyty, Ivan Halibei (field cleric of the Ukrainian Galician Army), Antin Tverdokhlib from Krakivets, Andrii Dolnytskyi from Siveriany, Hryhorii Muzychka from Zhuravno, Antin Siretskyi from Liatske Shliakhetske and others ${ }^{10}$.

The Polish authorities often arrested the priests regardless of state, age (90-year-old Counselor Berezovskyi was arrested), participation in political life. Often, the clergy humiliated, ridiculed before the settlers ${ }^{11}$. In Bortiatin the Sudova Vyshnia district polish people stole the church utensils. An embarrassing incident happened in Wiesloch Welykyi Syanok district. Polish riders entered the church, stole money, dressed "in church clothes and danced in the church, sprinkled with water in sacred water and sang "Eternal Memory"

In the Greek Catholic Metropolitan Ordinariate in Lviv it was noted that "the Greek Catholic Church creates a strong barrier against the Polonization of Eastern Galicia, ... trying to undermine and destroy the Church's influence on society and use all possible means"13. As of August 1921 in Drohobych and Rohatyn counties with 20-40 priests only 2-4 remained. The priests of Nyzhankivskyi, Zatorskyi, Lopatinskyi, Podliashetskyi, Halibei, Sukharevskyi were executed. The killings of the priests caused a noticeable resonance. The Presidium in Lviv, September 23, 1921, appealed to the Ternopil district Government to clarify the circumstances of the death of the priests of Nyzhankivskyi, Halibei and Pidliachetskyi ${ }^{14}$.

Sometimes the polish authorities provoked a conflict between the pastors and parishioners. Thus, the polish authorities sought to reduce the influence of the Greek Catholic clergy on Ukrainian society. October 30, 1921, the parishioners from Cherneve Mostyska district turned to the local pastor of Clementii Khotynetskyi with a request that he on November 1, 1921 sent the Service of God on the occasion of the third anniversary of the norising Ukrainian state, a memorial service for the dead Ukrainian soldiers. The priest refused because there was no consistory order. The parishioners believed that Khotynetskyi was not conducting cultural and educational work, but on the contrary, he attended posters and gendarmes: "Finds a common language with those who do not sacrifice Ukrainian institutions". Ukrainian parishioners were willing to pay a fee to Khotinetskyi from the local dramatic circle cash desk, but invited by Popel - the pastor with Malnivskaya Volia ${ }^{15}$.

Representatives of Ukrainian institutions in village Hhyriv wrote an appeal to the Przemysl ruler of Yosaphat Kotsilovskyi. The letter noted that Ukrainian institutions exist only from the estates of citizens, but priest Olshansky "provokes these institutions ... threatens to bring all conscious Ukrainians to the criminally harmful Ukrainians". "We want to have a priest who would work with us at one front" - noted in the letter ${ }^{16}$.

The higher clergy also suffered persecution. In November 1918, in connection with the "separation in political life", a search was carried out at the premises of the Przemysl bishop Josaphat Kotsylovsky. The polish officer, Karminsky, behaved unceremoniously with the Ukrainian lord Yo. Kotsylovskyi.

\footnotetext{
${ }^{10}$ Центральний державний історичний архів України у Львові (далі - ЦДІАУ у Львові). Ф. 408 (Грекокатолицький митрополичий ординаріат м. Львів). Оп. 1. Спр. 47 (Обіжники, розпорядження, протести, скарги, списки арештованих та ін. документи про переслідування греко-католицької церкви польською владою 1919-1938 рр.). Арк. 3, 8.

${ }^{11}$ Державний архів Тернопільської області (ДАТО). Ф. 231. Оп. 1. Спр. 325 (Скарга Львівського грекокатолицького ординаріату про переслідування духовними органами влади. Переписка 3 Міністерством віросповідання і повітовими староствами по цьому питанню). Арк. 3, 13.

12 Ibid. Арк. 15.

${ }^{13}$ Ibid. Арк. 13.

${ }^{14}$ Ibid. Арк. 17 зв.

${ }^{15}$ Archiwum panstwowe w Przemyslu. Inwentarz zesp. 142 (Archiwum Biskupstwa greckokatolickiego w Przemyslu. T. 2). Sygn 4157 (Sprawy karności księży. Sprawy mayątków cerkiewnych i parafialnych 1921). Kartka 223, 224, 260.

${ }^{16}$ Ibid. K. 404, 405.
} 
A considerable resonance in the East Galicia society was received by the polish authorities, Metropolitan of the Greek Catholic Church, Andrei Sheptytskyi, on May 23, 1923, at the monastery of the Sharytky in Poznan. From different corners of Galicia, the clergy of the Greek Catholic Church sent a letter of protest addressed to the president of the Rich Pospolyta Stanislaw Woitsekhowskyi: "The Prince of the Church and the defender of his believers became again the victim of coercion", shining with the aureole of martyrdom in the king's prisons, broken by a severe illness" ${ }^{\prime 17}$.

The priests of Berezhany (Bohdan Korduba, the canon of the Lviv chapter, Omelian Korduba, Ivan Romanchukevych, Pylyp Sverchuk from Vilkhivtsi, o. Stefan Komar - pastor village Tseneva, Ivan Pinkovskyi - pastor village Vybudiv) ${ }^{18}$ and Bobretskyi deanery (Victor Nestorovych, Volodymyr Dorosh, Mykhailo Kravchuk) of the Lviv archidiocese took part in numerous meetings with the participation of Ukrainian public-political and educational leaders in September 1923. A similar protest was sent from the dean's office to Bobritsky on September 27, 1923. Letter-protest parish governments were also supported by Busk, Voynyliv, Halych, Zolochiv, Kalush, Kolomyia, Olesko, Tlumach, Pidhaitsi, Rohatyn, Stryi, Ternopil, Peremyshliany and others. Ambassadors to the polish sejm, H. Prystupa and A. Pashuk, adopted a special resolution of Ukrainian ambassadors to the embassy's Diet with the requirement to immediately release from the arrest of metropolitan

A. Sheptytskyi ${ }^{19}$.

The Greek Catholic clergy showed remarkable activity during the September 1921 census. Ukrainian political leadership in Eastern Galicia urged Ukrainians to strongly boycott the census in order to deprive the polish diplomacy of the argument that the Ukrainian population allegedly recognized the Polish affiliation. This gave the polish government the opportunity to take security measures, to send a large number of troops, to observe the behavior of Ukrainians, including priests. The Minister of Internal Affairs of Poland sent a telegram to all district directorate in Galicia to monitor the situation, find out the forms and nature of the boycott, the social composition of the boycotts, and so on. In response, the chief noted that boycotts took place in all districts of the region, including Zhydachiv, Kolomyia, Kosiv, Nadvirna, Pechenizhyn, Bohorodchany, Dolyna, Tlumach, Stryi, Rohatyn, Kalush and Sniatyn ${ }^{20}$.

Most, according to the polish intelligence services, "disturbed the peace", "ruska party" and the Greek-Catholic clergy. In particular, statistical materials were stolen in the Hlushkiv Horodenka district. In addition, in Horodenka district initiators of the "anti-cessionary action" were the representatives of the country cooperative in Horodenka. The polish secret services noted that the population counted the most "population of people" in Torhovytsia, Rashkiv, Tyshkivtsi, Verbivtsi, Korniv, Kolinky, Daleshove and Hlushkiv, where the branches of the cooperative were just working. In Torhovitsa and Rashkiv, the army had to mix up to normalize the situation. In the store-cooperative in Horodenka, the appeal "From the house to the house from hand to hand" was distributed. In Sniatyn region, ukrainian women in the village Belleluia municipality, according to the polish intelligence services, threatened the police ${ }^{21}$.

\footnotetext{
${ }^{17}$ Центральний державний історичний архів України у Львові (далі - ЦДІАУ у Львові), Спр. 50 (Протести духовенства деканатів у місцевостях на букви Б-С. звернені до польського президента Войцеховського Станіслава у зв'язку з арештом митрополита Шептицький А. в монастирі Шариток у Львові). Арк. 3.

${ }^{18}$ Ibid. Арк. 4, 5.

${ }^{19}$ Центральний державний історичний архів України у Львові (далі - ЦДІАУ у Львові). Ф. 408 (Грекокатолицький митрополичий ординаріат м. Львів). Оп. 1. Спр. 584 (Резолюція посольського віча українських послів до посольського сейму Приступи X. і Пашука А. з вимогою негайно звільнити 3-під арешту митрополита А. Шептицького). Арк. 1.

${ }^{20}$ Державний архів Івано-Франківської області (ДАІФО). Ф. 2. Оп. 1. Спр. 31 (Донесення воєводського управління міністерству внутрішніх справ про бойкот перепису населення, який проводили українці Станіславщини). Арк. 1-3.

${ }^{21}$ Державний архів Івано-Франківської області (ДАІФО), Ф. 2. Оп. 1. Спр. 31 (Донесення воєводського управління міністерству внутрішніх справ про бойкот перепису населення, який проводили українці Станіславщини). Арк. 8.
} 
The general population census of 1921 turned into a kind of anti-occupational plebiscite, and a significant role played by the Greek-Catholic clergy. Characteristically, for example, pastor Vasyl Nimyi, argued for the boycott of the census that "Eastern Galicia lies outside the borders of the Rich Pospolyta of Poland, therefore it is not subject to the population census". Particularly dangerous for the Polish authorities was the situation in the Kosiv district where Greek Catholic priests: V. Stefanovych,

I. Donihievych and I. Berezovskyi were "declared enemies of the State and people of Poland and fierce Ukrainian agitators ... among the masses of the dark Hutsul peasantry". The Kosiv head of state even feared that the inhabitants of the district, under the influence of their campaign "in the event of unpredictable confusion, could explode, and the consequences could be catastrophic". As a result, the polish authorities used against them both arrests and fines, but this did not change the behavior of the clergy ${ }^{22}$.

The Minister of Religious Affairs and Enlightenment of the Rich Pospolyta Dunikovskyi issued an order to all masters of the governor regarding the role of the clergy in conducting the census. Heads in their reports noted opposition to the census of the population. Thus, the head of the Kamyanka Strumilova (now Kamianka Buzka) Marynovskyi in a letter to the district government in Ternopil said that the secret campaign against the census of the population was carried out by the ruska intelligentsia, teachers, "priests" and former officers of the Ukrainian Army". It was noted that in separate gminas of the district, which resisted the "conscription", it was necessary to send the army and, with the accompaniment of 10-20 frigates, send it to the gendarmerie. The posters of the State Police in a letter dated October 21, 1921 noted that a particularly difficult situation was found in Zalishchyky, as well as in the settlements of the district - Tovste, Mylivtsi. Instead, in the communes of Shypivtsi, Holovchyntsi, Korolivka, Solone, Rozhanivka, Anhelivka Zalishchyky country, the population census took place in the whole without incident ${ }^{23}$.

The letters to the police said that people under the influence of agitators should not go to the census "work in the field, dig potatoes or work on winter wheat fields". And the "old people" deliberately attracted the attention of commissars, which made them impossible to fulfill their duties. Mykhailo Yahelskyi - Greek-catholic pastor Kamienka Strumilova and Petro Harych did not fill in the headings of "Citizenship", Ivan Kozlov and Vasyl Lisko refused to send a suspension of confessions against a conscription. Priests Ivan Kurchav and Petro Pelech from Silets, near Chervonohrad, recognized that they belonged to Eastern Galicia. Priests: Ivan Pylypets, Hrygoryi Plakida of Novyi Scalat, Volodymyr Kunitskyi of Orykhovets, Vasyl Bachinskyi of the Zherebky Korolivskyi during the population census in the countryside recognized citizenship of the Rich Pospolyta, but the lists indicated a remark about themselves as Ukrainians ${ }^{24}$. The caveats of the polish secret services were in relation to priest Bohdan Montsibovych from Chortkiv, "which was to be investigated". The priest of the Apolinarius Chemerynskyi from Budaniv, Terebovlia district, wrote the "Western Ukrainian Republic" in the district in the circle. At the same time, the representatives of the special services in their reports of January 4, 1922 noted that often cases of resistance to the census in Galicia were sporadic. "General cases" and "fundamental resistance" took place only when the "russka intelligentsia emerges" 25 .

The clergy of the Greek Catholic Church took an active part in the development of Ukrainian statehood during the time of the ZUNR. To a large extent, precisely because of this, the above clergy and a significant portion of the lower were persecuted by the Polish authorities. The priests hoped for a legal settlement of the East-Galician issue at the international level in 1919-1921. That is why the majority of the Greek Catholic clergy contributed to the boycott of the population census of 1921. The

\footnotetext{
22 Делятинський Р. І. Діяльність духовенства Станиславівської єпархії УГКЦ в умовах утвердження польського окупаційного режиму (1920-1923рp.). URL : http://thule.primordial.org.ua/mesogaia/ delyat03.htm. (дата звернення: 5 червня 2019 р.).

${ }^{23}$ Державний архів Тернопільської області (ДАТО). Ф. 231. Оп. 1. Спр. 9 (Інформації повітових староств про агітацію яку поводять українські націоналісти проти перепису населення на території Тернопільського воєводства). Арк. 16, 18.

${ }^{24}$ Ibid. Арк. 61.

${ }^{25}$ Ibid. Арк. 91, 92.
} 
priests mostly reacted to the establishment of the "Polish state of occupation", which was manifested predominantly in the refusal to recognize Galicia and preserving their own national identity. The clergy carried out active public and cultural-educational work among the people. To a large extent, such a position of the clergy was influenced by the pastoral letters of the episcopate, in particular metropolitan A. Sheptytskyi, bishops of H. Khomyshyn and Yo. Kotsylovskyi.

\title{
THE REPRESSIVE POLICY OF THE POLISH AUTHORITIES AGAINST THE GREEK CATHOLIC CLERGY 1919-1921
}

\author{
Oleh YEHRESHII \\ State Higher Educational Institution \\ "Vasyl Stefanyk Precarpathian National University", \\ Department of History of Ukraine and methods of teaching history, \\ Shevchenko St., 57, 76018, Ivano-Frankivsk, Ukraine \\ e-mail: ludyna@ukr.net
}

\section{Summary}

In the scientific article, the author reveals the attitude of Polish government structures to the Ukrainian Greek Catholic clergy in Galicia in 1919-1921. The author defines the nature of repressions against priests in this region.

On June 22, 1919 many Greek Catholic priests from different parts of Galicia: Anatol Dolyńskii, Ivan Halibei, Mykola Nyklych and others were taken to Lviv prison "Bridgits" without any guilt. Some of the priests founded themselves in a camp for prisoners at Stshalkovo near Poznan. The higher clergy also suffered persecution. In November 1918, in connection with the "separation in political life", a search was carried out at the premises of the Przemysl bishop Josaphat Kotsylovsky. The polish officer, Karminski, behaved unceremoniously with the Ukrainian lord Yo. Kotsylovskyi.

The scientific article also notes that the Greek Catholic clergy showed marked activity during the census of the population in September 1921. The general population census of 1921 turned into a peculiar antioccupational plebiscite.

Keywords: Greek Catholic clergy, repressive politics, Polish governmental structures, confinement, arrests.

\section{REFERENCES}

Archiwum panstwowe w Przemyslu. Inwentarz zesp. 142 (Archiwum Biskupstwa greckokatolickiego w Przemyslu. T. 2). Sygn 4157 (Sprawy karności księży. Sprawy mayątków cerkiewnych i parafialnych 1921). Kartka 223, 224, 260, 404, 405.

Deliatynskyi R. I. Diialnist dukhovenstva Stanyslavivskoi yeparkhii UHKTs v umovakh utverdzhennia polskoho okupatsiinoho rezhymu (1920-1923 rr.). URL: http://thule.primordial.org.ua/mesogaia/ delyat03.htm. (data zvernennia: 5 chervnia 2019 r.). [in Ukrainian].

Deliatynskyi R. I. Stanovyshche ta diialnist dukhovenstva Stanislavskoi yeparkhii UHKTs v 19191920 rr. Visnyk Prykarpatskoho universytetu. Istoriia. Vyp. VII. Ivano-Frankivsk, 2003. S. 69-77. [in Ukrainian].

Deliatynskyi R. Rehuliuvannia pravovoho statusu hreko-katolytskoi Tserkvy v konteksti podii radiansko-polskoi viiny u 1920-1921 rr. (na prykladi Stanislavivskoi yeparkhii). Ukraina soborna : zbirnyk naukovykh statei / red. kol.: O. P. Reient (vidp. red.) ta in. Kyiv : In-t istorii Ukrainy NAN Ukrainy, 2005. Vyp. 2. Ch. 2 : Sotsiokulturni, etnokonfesiini ta demohrafichni problemy formuvannia ukrainskoi natsii. S. 309-320. [in Ukrainian].

Derzhavnyi arkhiv Ivano-Frankivskoi oblasti (DAIFO), F. 2. Op. 1. Spr. 31 (Donesennia voievodskoho upravlinnia ministerstvu vnutrishnikh sprav pro boikot perepysu naselennia, yakyi provodyly ukraintsi Stanislavshchyny). Ark. 1-3, 8 .

Derzhavnyi arkhiv Ternopilskoi oblasti (DATO). F. 231. Op. 1. Spr. 325 (Skarha Lvivskoho hrekokatolytskoho ordynariatu pro peresliduvannia dukhovnymy orhanamy vlady. Perepyska z Ministerstvom virospovidannia i povitovymy starostvamy po tsomu pytanniu). Ark. 3, 13, 15, $17 \mathrm{zv}$.

Derzhavnyi arkhiv Ternopilskoi oblasti (DATO). F. 231. Op. 1. Spr. 9 (Informatsii povitovykh starostv pro ahitatsiiu yaku povodiat ukrainski natsionalisty proty perepysu naselennia na terytorii Ternopilskoho voievodstva). Ark. 16, 18, 61, 91, 92. 
Haikovskyi M. UHKTs v chasy mytropolytuvannia Andreia Sheptytskoho. Kyivska Tserkva. 2001. № 2-3. S. 32-48. [in Ukrainian].

Komar V. L. Kontseptsiia prometeizmu v politytsi Polshchi (1921-1939 rr.). Ivano-Frankivsk : Misto NV, 2011. 360 s. [in Ukrainian].

Krasivskyi O., Pylypiv I. Mytropolyt Andrei Sheptytskyi i polska derzhava (1918-1923 rr.). Ukrainskopolski vidnosyny $v$ Halychyni u XX st. : materialy mizhnarodnoi naukovo-praktychnoi konferentsii (21-22 lystopada 1996 r.). Ivano-Frankivsk : Plai, 1997. S. 152-155. [in Ukrainian].

Marchuk V. Ukrainska Hreko-Katolytska Tserkva. Istorychnyi narys. Ivano-Frankivsk : Plai, 2001. 164 s. [in Ukrainian].

Marchuk V., Pylypiv I. Ukrainska Hreko-Katolytska tserkva y ukrainska derzhava. Ukrainoznavchi studii. 2000. № 2. S. 205-223. [in Ukrainian].

Perevezii V. Hreko-katolytska tserkva v umovakh ukrainsko-polskoi konfrontatsii 20-30-kh rr. XX st. Kyiv, 1998. 46 s. [in Ukrainian].

Pylypiv I. V. Hreko-katolytska tserkva v suspilno-politychnomu zhytti Skhidnoi Halychyny (19181939 rr.) : monohr. Ternopil : Ekonomichna dumka TNEU, 2011. 440 s. [in Ukrainian].

Tsentralnyi derzhavnyi istorychnyi arkhiv Ukrainy u Lvovi (dali - TsDIAU u Lvovi), Spr. 50 (Protesty dukhovenstva dekanativ u mistsevostiakh na bukvy B-Ye. zverneni do polskoho prezydenta Voitsekhovskoho Stanislava u zviazku z areshtom mytropolyta Sheptytskyi A. v monastyri Sharytok u Lvovi). Ark. 3-5. [in Ukrainian].

Tsentralnyi derzhavnyi istorychnyi arkhiv Ukrainy u Lvovi (dali - TsDIAU u Lvovi). F. 408 (Hrekokatolytskyi mytropolychyi ordynariat m. Lviv). Op. 1. Spr. 47 (Obizhnyky, rozporiadzhennia, protesty, skarhy, spysky areshtovanykh ta in. dokumenty pro peresliduvannia hreko-katolytskoi tserkvy polskoiu vladoiu 19191938 rr.). Ark. 3, 8.

Tsentralnyi derzhavnyi istorychnyi arkhiv Ukrainy u Lvovi (dali - TsDIAU u Lvovi). F. 408 (Hrekokatolytskyi mytropolychyi ordynariat m. Lviv). Op. 1. Spr. 584 (Rezoliutsiia posolskoho vicha ukrainskykh posliv do posolskoho seimu Prystupy Kh. i Pashuka A. z vymohoiu nehaino zvilnyty z-pid areshtu mytropolyta A. Sheptytskoho). Ark. 1. 